\title{
Why Can't I Be You
}

\author{
Ailsa Kay
}

Why Can't I Be You traite des mécanismes d'identification et de nonidentification à l'autre qui surviennent en amour et qui se traduisent par différents phénomènes de méconnaissance dans la relation entre Alexandra, une femme minuscule et féminine, "douce comme un oiseau », et William, un homme lourd, studieux et « constipé, » ayant « les mains comme des jambons et les cuisses comme des flancs de bœuf ». Leur mauvaise lecture respective de l'autre atteint son parowysme lorsqu' Alexandra tue le lapin que William lui a apporté comme animal de compagnie, témoignage de son affection, geste qu'Alexandra rejette, cédant plutôt aux fantasmes de «ce à quoi ressemblerait l'amour entre ses mains fortes, la poussant contre le mur de telle façon, entrechoquant bruyamment la vaisselle, le rebord en saillie du buffet contre sa colonne vertébrale, les coutures déchirées, les ecchymoses de ses mamelons... »William préfère « la courtiser à travers Eschyle, Sophocle et Plotin... l'éblouir avec des mots, la distraire avec des mots ».

The kitchen where they sit in autumn's early night, is all shining planes of chrome, false bright, every surface reflective: the vinyl of the table-cloth where light pools, the plastic lid of the butter dish, ceiling suspended in it, the curve of the electric toaster.

Alexandra faces her husband across the kitchen table. Her hands are cold and stiff. Her stockings are ripped. The green twinset bought just that month from the Sears catalogue is stained and damp and she recognizes it smells. Of sweat and rabbit and wet wool. "I'm tired William," she says, "just tired."

"I know." And his voice is round as a boulder sunk into the hill, and filled with the shade of maples. When she first met him, he'd had his chest up against the flank of a horse, holding the animal steady with only the weight of himself. When she first touched him, his cock in her hand had been hard and sure.

"Eat," he says. "You'll feel better." What he means is: swallow. 
She was soft as a swallow in her blue dress the day he first saw her in the barn. She was air, a corner of sky torn at the edges, blown suddenly into his peripheral vision. She brought him lemonade and he'd held the cold glass to his lips before he even knew her name. "Alexandra," and she smiled.

Driving back to town that afternoon, William held the picture of her in his eye - the pale cream of her forearm as she handed him the glass, her blond curling hair. He'd never seen anything so dainty. So slight. She could fly, that girl, so light was she. Pure poetry. Maybe he'd make some inquiries.

"Poetry? I don't think so. She likes music though. Why?" Sally arched her brows at him, sliding his mail across the counter.

"Just curious," he stuffed the mail into his inside pocket, "No reason," and left the post office in a blush of pink, Sally chuckling after him.

That evening, William sat reading on the can as he generally did, bowels straining. Longinus, tonight - the sublime. He was striving for sublimity. William put the book between his feet, elbows on his knees. His hands were like hams, his thighs (he looked at them) like sides of beef. Could he imagine her pretty fingers in that hand? Pale legs against that thigh? Alexandra. Not sublime but lovely, according to Longinus, a lesser species of beauty. Perhaps Longinus had never seen loveliness like this, though, soft as a bird. Perhaps he hadn't known what it was to want it.

William mopped his forehead with a corner of shirt, made his decision, stood.

They'd been married nine months already by the time he surprised her with the rabbit. He'd driven home with it on his lap, imagining her happiness, sweet forgiveness. But when he put it in her palms, only anger. She'd looked at the rabbit, looked at him, looked at both of them like they were the most ridiculous creatures she'd ever seen. And she might have been right.

Yet when he first held her hand it was like a rabbit in his fist. They sat facing each other in Meryl's Restaurant. She had french fries and a coke and William had a milkshake - his delicate intestine. She wore her blue dress, same blue dress as she'd worn when they first met. Maybe it was her good dress. Maybe she'd put it on just to bring him a glass of lemonade, carry it careful across the lawn in her hand, and into the dim of the 
low-roofed barn, for him. He'd like to think so. He didn't believe it. $\mathrm{He}$ had to distract her, distract her from his hands like hams, body built like a brick-shithouse (as his mother used to say). Letting go her hand and taking a pen from his shirt pocket, then holding a napkin carefully, neatly in front of him on the table, he wrote. When she tried to read it, bending her head close, he sheltered the words from her view until complete, when he pushed it across the table.

Since my soule, whose child love is

Takes limmes of flesh, and else could nothing doe,

More subtile than the parent is,

Love must not be, but take a body too.

You!

The "you" was circled in a heart, lopsided and gently drawn. "I didn't actually write that," William said, watching her eyes move as she read.

That afternoon, the afternoon of their first date Alexandra had perched on the edge of her bed, pulled the sheerest of sheer stockings over her legs, bed creaking as she shifted closer to the small mirror on the dresser. Powder with a soft puff. Lips the inside of roses, dark as pockets. A spill of perfume at the neck. Blush. She'd leaned in closer to finish her eyes, the dim bulb on the ceiling not bright enough, sunlight filtered through green curtains - air the colour of young cabbage and stifling hot. She stood at her bedroom window feeling the slow trickle of perspiration between her breasts, waiting for William.

He drove a blue Ford pick-up. She thought how she would dangle one arm, nonchalant, out the window, feel the wind lifting it, tugging at her fingers. He would fiddle with the radio to cover over the silence, awkward for not knowing what to say. When they walked together, she'd feel so small on his big arm. "He's kind of a strong silent type," Sally had told her when Alexandra had asked for information. "He blushes easy. And he reads a lot." Alexandra thought, that's all she'd ever wanted. Heavy silence to balance her own slightness, to hold her down. "He's a catch," Sally said.

A cloud of dust on the gravel road and there he was, all six and a half feet of him, climbing out the cab of his dusty blue Ford. Lumbering her way. 
As he told her about his childhood, Alexandra sipped her Coke through a straw. He liked animals, he said. And he liked his job but really, if he'd had his choice, he would have studied words. Aeschylus, Aristotle, Augustine. Alexandra lowered her eyes. He had hands like her brothers' square, dark tanned, dirty under the nails a bit even though he'd obviously scrubbed. She liked the hair on the backs of them, the way they looked bleached. His conversation seemed to circle, repetitive. His father had been a veterinarian - she probably knew that. Alexandra nodded, yes. Seemed like a good enough profession, like a good enough thing to do with a life. But words, he said, that's where his heart was. And he withdrew a pen from his pocket, a napkin from the dispenser.

She read the poem, folded it up. "You don't need to be a poet to impress me, Mr. William Derby" she said, smiling. She put the napkin in her handbag, clicked it shut.

"Just curious, eh," Sally winked at him the next time he walked into the post-office. "And did you have a good time?"

On the ceiling, a fan churned and young Queen Elizabeth in pale blue dress looked down from her place on the wall as paper softly shuffled from hand to hand, hand to box. William cleared his throat, scratched the back of his neck. "You do like to embarrass a man, don't you?"

"That I do," Sally laughed, turning to scoop his mail from a box behind her, "I'll tell you a secret though," she leaned over the counter and beckoned him closer. "She's surely likin' you." He walked out, heart knocking. He would woo her next with Aeschylus.

He would woo her with Aeschylus, Sophocles, Plotinus. He would read with her in his arms. With her in his arms, Plato's Phaedrus, Longinus. He would dazzle her with words. He would distract her with abstraction. $\mathrm{He}$ would show her what he longed to be. That night on the can with the presocratics, his blessed bowel moved. He underlined the phrase: "As our souls, being air, hold us together, so breath and air embrace the entire universe." And felt himself lighter, for just a moment. For just a moment transcendent.

The strong silent type, Sally had said. And Alexandra had believed her. When Sally got married, she'd called Alexandra, just like she'd promised to, from the hotel in St. Catherine's where they were spending their honeymoon. Across the crackle of long-distance, Sally had said, in her cheery 
public voice, "The view from our room is splendid." And Alexandra, standing in the kitchen with her father at one side of her head and her mother at the other, had had to stifle a giggle. "Our room is small but cozy" would have meant less than the expected six inches.

Thanks to Sally and the novels she lent her, Alexandra knew a great many second-hand things about men, about William before she knew him. The first thing: he was six and a half feet tall and big boned. That meant he'd be both long and wide. The second thing: he was strong and silent. That meant she could expect stumbling words, long spells of quiet. She wouldn't wait for him to say "I love you." No, love would be in his hands, strong hands, the way he pushed her back into the wall, in clattering dishes, the jut of cupboard handle against her spine, in ripped seams, bruised nipples. That's how it worked, she'd thought.

But then.

"Close your eyes!" he'd shouted up the stairs, his voice reaching her where she sat at her bedroom window, trying to pick up a dropped stitch. She put her knitting in her lap, a swath of the softest robin's egg blue. Eyelids lowered, Alexandra sang out, "I can't see you!" Maybe he'd brought her a real present this time, not the poems and scraps of paper he usually folded into her palm. Or read out loud in the heavy, round voice she'd fallen in love with but which, when he sounded out those rhyming syllables, was only laughable. She heard the thunk of his workboots on the hallway linoleum, the creak of stairboards. She felt his hands on hers, disengaging fingers from yarn, from knitting needles, making her palms into a bowl.

"What's this?" she opened her eyes. Rabbit cowering there.

"What's it look like?"

Alexandra felt her throat close, her face flush. Such a soft and useless thing. A scared thing. And there he was standing there with the beginning of a grin falling off his face, looking nearly as scared as the animal.

William scratched at the chest hair under his shirt, a shirt that was wrinkled from driving around all afternoon, stained under the armpits, reeking of barn and sweat. He seldom came to her this way, smells still clinging. Usually it was a bath first. Usually, before he kissed her, he smelled of lemon and lilac. He called it making himself presentable. Didn't matter that she told him how many times she didn't care for presentable. Didn't matter she teased him for his endless bathing. And now here he stood, and for this. "I thought you might like a pet. Windebanks had a 
whole litter of 'em. Too many for the kids to keep." He had apology in his voice, a shrug, "This one made a run for it."

She waited, staring at him, silent.

William leaned over, took the rabbit from her hands. "It's okay. I'll take care of it."

So maybe the rabbit had been a bad idea. After taking it from his wife's palms, he'd searched the back porch for a suitable box. He'd held the squirming animal in one hand against his chest as he moved rusting gas cans, bits of wood, pieces of furniture, old coats with the other. He had to concede that he didn't know the first thing about them. Except they ate carrots. More bother than it was worth, no doubt and besides it hadn't done what he'd meant it to. When he'd driven home, rabbit on his lap, he'd imagined happiness, sweet forgiveness. Her eyes would fill with tears and she'd say, "I'm sorry, William. I don't know what got into me."

It was Aquinas that started it. The two of them nestled each into a corner of the couch, William with a book and a cup of camomile to settle his stomach, Alexandra with her knitting. The sound of her needles: clickclick, pause as she pulled more yarn from the ball at his feet. Aquinas. "- for the sun alone does not generate man, but in man himself there is the power of begetting man; and in like manner with other perfect animals. Now among these sublunary things nothing is more perfect than the human soul." He read it out loud. "Sublunary things," he'd never read any word more perfect.

But Alexandra, from the other end of the couch, "Could you not, for once, be quiet? Always talking. Talking and reading. Those stupid books. They can't birth a calf, you know. Can't put food on the table. Can't lift a goddamn finger, so what good are they?"

He looked up to see her eyes sharp on the needles. Angry click-clickpull. He opened his mouth to tell her what they could do, what they did do, those words, but she cut him off. "Don't. Don't you dare say one more word, you hear me? I've had it up to here."

She pitched her hand at her chin.

Now, William found a wood crate, took the paint tins out of it, put the rabbit inside. Still quivering, it curled itself into the corner. Dumb thing.

What had happened? Before they were married, she'd laid her head on his lap as he read to her from Ovid. As he read to her from Ovid, she'd laid 
her head on his lap and unbuttoned his fly. Button by button, she'd done it. Reached delicate fingers in to stroke him there. And him growing hard with her lips so close, and her hair curling round her pretty face and her long fingers reaching in. My God, and he thought he'd die but he just kept going like nothing was happening as those pretty fingers closed around him in a fist.

Then both of them suddenly too nervous to move - her hand gripping his penis like a stick, his voice going on and on. And on and on - the death of Pentheus. How long did it take them to get themselves out of that one? He read until he was limp, and she finally withdrew. After they were married, they'd laughed about it. Collapsed giggling into each other at the thought of it. From the first date to their wedding day only five months. From summer into fall. Two seasons of guessing through clothes that never came off. And then after they were married, that very day, she lifted the skirts of her wedding dress and crawled on top of him. Acres of tulle and taffeta and he could see nothing of her, her legs straddling him, could only feel as she unbuttoned his pants, the coolness of long fingers on him, and him quickening. Taffeta skirts rustling like a thousand birds around him, the speed of their heartbeats in her fist fluttering. Sudden shock of wings.

"You are so beautiful," he said, reaching up to touch. She closed her eyes.

He had spoken to her of Plato, this woman. He had told her a million things - both socratic and pre-socratic. She'd always listened. And then suddenly over Aquinas. That tone in her voice like hate.

Those words, words without fingers she hated so much, they were not useless. Not stupid. They lightened him. Like birds, they lifted him. Without words, he knew, he would harden. He would solidify, feet anchored to the ground, held captive by his own cumbersome flesh. Without words there would be no flight - from the manure on his boots, smell of animal on his hands, his own unrelieved straining at least once a day on that toilet, pushing and cursing against his own immoveable gut. There would be no distance between him and the boils he lanced, the hooves he scraped, the udders swollen and beginning to stink.

She hated him.

The next day, in a humid cell of hay and manure William gripped a cow by its insides the way his own gut gripped him from the inside. In the near-dark of the barn, the animal at the end of his arm shuddering and 
kicking, he told himself the words again, wishing for them to take him out: "As our souls, being air..." he said. Blood and shit under his fingernails as he knotted the rope.

Alexandra knew her husband's habits. After coming home from a farm call, William would take his clothes off in the kitchen, leave them in a box by the side door which he would later take down to the basement where the laundry tubs were. Naked, he would tiptoe to the bathroom - treading as though he thought his bare flesh noisier than clothed. Leaving the door open, he would run his bath. Steam billowing into the narrow hallway, carrying the scent of lemon to pull the barn smells from his pores. Astringent, was his word for it. Then sinking his mass into the tub he'd breathe out in short puffs - "Hot. Hot. Hot." - until he was submerged almost to his chest in scalding water. There he would soak. For up to an hour he would sit, rubbing his belly, skin reddening with heat and sweat pouring from his forehead.

"Alexandra?" his voice reached her as she sat downstairs at the kitchen table peeling carrots for the evening's dinner. "A cup of tea if you have a minute?"

The moment she stepped into the bathroom her hair was wet, condensation dripping from the mirror, from the window, steam entering her throat, weighting her light cotton dress. Her husband's soft girth filled the tub, soft and pale pink but for his face, neck, and forearms which were tanned dark. His soft stomach trembled with every breath. Penis curled tiny and pink into the hair of his groin - a baby's fist. She placed his teacup by his elbow on the shelf. "Stew for dinner," she said. And turned to go.

"I think I'll be fine with an omelette tonight, thanks darling." The teacup in his hand was a thimble he blew into before sipping.

The kitchen was watery with September light. Stew in the pot on the stove, table in the corner set for two. A plate of sliced bread, green plastic butter dish, salt and pepper in glass shakers. The screen door let in the sound of the neighbour's dog. Alexandra cracked three eggs into a bowl. The sound of angry whisking the only noise from inside.

Minutes later, he emerged. Stole up behind her, placed a kiss on the back of her neck.

"Sit down. Dinner's almost ready." 
His face was still pink from the tub, his hair wet and slicked back. Alexandra sat across from her husband and watched as he ate that omelette, one small bite at a time. Blowing on each forkful before putting it in his mouth. She swallowed hard. Tried not to be angry again. Tried not to look at him. Tried not to see the stomach trembling underwater, the baby fist. She shoved her chair back from the table, yanked the plate out from under him. "I don't know why you married me." Ran water hot and angry into the sink.

William stood up slowly. He went to the fridge, pulled out a stalk of old celery.

Alexandra watched her husband through the window as he slouched toward the hutch. He'd built it two months ago, in the middle of summer, the day after he'd put the rabbit in her hands. She'd thought he'd drown it or take it back to Windebanks but no, he'd made a home for it. He cared for it. She watched him now squatting there, all six and a half feet of him, feeding greens to a bunny.

She had expected none of this.

"You are so beautiful," he'd said to her on their wedding night and Alexandra had blushed. She was; she felt she was. She was a beautiful, blushing bride. She wanted to feel him inside. Men. This large man she held between her knees. Her whole body shook, trembled from the effort of balancing, thigh muscles quivering.

"Hold onto me," he said, holding out a finger. She took it. "Now, look at your hand."

She looked. "Fingernails like little pink bird beaks." She smiled, stroking him, with her other hand, beneath her skirts. How hard he would get. How deeply he would come into her.

"So perfect you are," he said, longingly. "Like a bird." And Alexandra felt William's other hand on her leg, beneath her skirts, rustling. "Light, light as a bird." As he came into her first not with his cock which she gripped, now, uncertainly, but his with his littlest - his baby - finger.

She hadn't killed it herself, had asked Henry from the butcher shop if he'd mind doing it for her. He showed up at her kitchen door one November afternoon and said: "Right then. You're sure about this, are you?"

"I'm a farm girl, Henry. As far as I'm concerned, animals are for eating." She wore a twin-set that day, mint green. 
"I can likely find my own way," Henry mumbled, shuffling awkwardly on the step as Alexandra bent to take her slippers off, pull rubber boots over her dainty feet.

"You likely can, but that's fine. I need a breath of fresh air." She grabbed one of William's old barn shirts off a hook and threw it around her like a blanket. "Let's go." She hadn't once been out to the hutch. She'd watched William build it. Watched him kneel there like imbecile, soft in the head. Watched him hold the animal gently as he held her. Gently as he always held her.

Now swift, Alexandra stepped over the chicken wire, lifted the roof off the cabin and in one practiced gesture, hooked the animal by its ears in her fist. "There you go, Henry. I really appreciate this."

In less than a second, it was slit.

William noticed his wife as soon as he stepped out of the truck. She stood on the river bank, still wearing his old shirt. Her legs storkey in their stockings and boots.

"Alexandra?"

She had expected it to be fast, but not so sudden. Had expected the blood but not the smell of it. Henry held the rabbit by its ears.

"Thank you, Henry," her mouth dry.

"Well, I'll just clean it up and skin it for you, shall I? Bring it in to you when I'm done."

Now William stood beside her, his hand reaching for her elbow as though wanting to support her, but nervous, as always, to touch.

"Don't," she said. Yanked her arm away.

She walked back through the snow, leaving William alone out there with his rabbit house, rabbit carcass where she'd told a confused Henry to leave it. Just leave it. She'd take care of it. She left William out there and stomped into the kitchen and up the stairs without taking her boots off.

She ran a bath. Turned it on full, furious hot water steaming loud against enamel. Then, the picture of his floating belly in her mind, shut the water off. She sat, slumped on the edge of the tub, in her twin set and her rubber boots, stockings ruined from where she'd knelt.

There had been no last straw. She'd just gotten fed up, that's all. Fed up with his soft shoulders, his plump hips, his belly with its baby skin, his childish lips, his nuzzling, his whimper when he came. Yet the first time 
she'd seen him, he'd had his chest up against the flank of a horse, holding the animal steady with only the weight of himself. His cock in her hand had been hard and sure.

William found her there an hour later on the edge of an empty tub. $\mathrm{He}^{\prime} \mathrm{d}$ carried her downstairs, sat her down at the kitchen table and told her not to move. Eat. Swallow.

In the end they emerge from the body without wings, it is true, but having made a strong effort to achieve them; this is no mean prize, and it comes to them from the madness of love. Those who have already begun their heavenward journey the law does not compel to go down into the darkness beneath the earth: they pass their time journeying happily together in the brightness of day, and together, when the time comes, they receive their wings, because of their love. 